\title{
Bence-Jones Protein Measurement
}

National Cancer Institute

\section{Source}

National Cancer Institute. Bence-Jones Protein Measurement. NCI Thesaurus. Code

C111136.

The determination of the amount of Bence-Jones protein present in a sample. 